\title{
円管における隔膜の開口過程が衝撃波強さに及ぼす影響
}

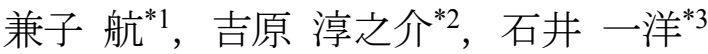

\section{Effects of opening process of diaphragm on shock strength in a circular tube}

\author{
Wataru KANEKO ${ }^{* 1}$, Junnosuke YOSHIHARA ${ }^{* 2}$ and Kazuhiro ISHII ${ }^{* 3}$ \\ ${ }^{* 1,}{ }_{22, * 3}$ Department of Mechanical Engineering, Yokohama National University \\ 79-5 Tokiwadai, Hodogaya-ku, Yokohama-shi, Kanagawa 240-8501, Japan
}

\section{Received 1 October 2015}

\begin{abstract}
In the present work, high-pressure hydrogen is released to air through a circular tube and shock formation process has been studied using various diaphragms separating the high-pressure hydrogen from an ambient air. To improve reproducibility of diaphragm rupture, the diaphragms were scored by precisely controlling the depths of score. The rupturing process of the ruptured diaphragm was visualized by a high-speed camera so that opening ratio of the diaphragm was estimated. As a result, the rupture pressure can be obtained with good reproducibility by selecting appropriate diaphragm material and the depth of score. Thus opening process of rupturing diaphragm and shock formation can be well controlled. The opening ratio of diaphragms was predicted by a modified equation based on previous tests of diaphragm opening in rectangular tubes. In addition, higher opening rate of diaphragms generates a stronger shock wave, whereas smaller opened area leads to a weaker shock wave.
\end{abstract}

Key words : Shock wave, Shock tube, Shock wave formation, Diaphragm, High-pressure hydrogen

\section{1. 緒言}

近年，エネルギーの安定供給および二酸化炭素排出削減への取り組みから，水素はクリーンなエネルギー源と してその利用が拡大しつつある。特に水素を利用した燃料電池自動車は活発に開発されており，その利用拡大に 伴い水素インフラの整備も急速に進められている。一方で，水素はエネルギ一密度の低さから水素ステーション では高圧状態で貯蔵されることとなり，貯蔵容器における水素充填圧力は現在 $70 \mathrm{MPa}$ に達している.

水素ステーションや燃料電池自動車, 高圧水素貯蔵タンクにおける事故として高圧水素の漏洩が想定されるが, このシナリオは大きく二つに分けることができる(武野他，2005).一つは定常ピンホール漏洩で，これは配管継手 の取付け不備，溶接不良，腐食などに起因する配管等の微小な亀裂からの開放空間への小規模漏洩を意味する. この場合，漏洩量が少ないため漏洩口での圧力の減衰が大きく，例え漏洩したとしても水素の自発点火は確認さ れることはない，もう一つは非定常大漏洩で，高圧水素配管などが破断し大量の水素が開放空間に放出される場 合である.このとき, 通常は自発点火が発生することはないが, 漏洩箇所の周囲条件によっては点火源が無くと も自発点火・爆発を引き起こす可能性があることが確認されている(Dryer et al., 2007)(Golub et al., 2008)(Lee et al., 2013)(Mogi et al., 2009). とくに自発点火を引き起こす事象として, バルブの破損, 安全弁の作動, 燃料電池自動 車の事故による水素関連部品の破損などが考えられる.

これまで高圧水素漏洩による自発点火に関して，配管途中の隔膜を破断させることで漏洩状態を再現する実験 が行われている(Dryer et al., 2007)(Golub et al., 2008)(Lee et al., 2013)(Mogi et al., 2009). その多くは, 貯蔵容器と配

No.15-00541 [DOI:10.1299/transjsme.15-00541], J-STAGE Advance Publication date : 10 February, 2016

*1 正員, 横浜国立大学大学院工学府（†240-8501＼cjkstart神奈川県横浜市保土ヶ谷区常盤台 79-5）

*2 横浜国立大学工学部

*3 正員, 横浜国立大学大学院工学研究院

E-mail of corresponding author: kaneko-wataru-wt@ynu.jp 
管を隔膜で仕切り，高圧水素を容器に充填することで隔膜を破断し，多様な管路を通して水素を放出することで 自発点火の発生条件が調べられている，その結果，自発点火の発生メカニズムとして，漏洩時に生ずる衝撃波の 三次元的挙動により周囲空気が加熱され，この加熱された空気と漏洩した水素が混合することで境界層付近およ び管路中心で点火・爆発が生ずるというものが提唱されている(Dryer et al., 2007). このとき, 水素の充填圧力が高 く, 漏洩箇所下流の配管が長いほど自発点火が発生しや寸いことがわかっている(Golub et al., 2008)(Lee et al., 2013)(Mogi et al., 2009). しかしながら, 自発点火が生じる臨界水素圧力および配管長は研究者によってその值が 大きく異なり，同一条件下での実験においても自発点火発生の有無に相当なばらつきが見られる．このばらつき の主たる原因として，実験ごとに隔膜の破断状態が異なることが考えられる．すなわち，隔膜破断により水素は 管路内一漏洩するが, 隔膜の開口には有限の時間を要し, 開口開始から終了までに要する時間および開口の形状 によって，下流管路内に形成される衝撃波の強さならびに形成距離が異なることが考えられる. したがって，高 圧水素漏洩による自発点火発生条件を定量的に求めるためには, まず再現性の良い隔膜の破断を行う必要がある.

過去の衝撃波管内における衝撃波形成に関する研究において, 各種隔膜ごとに開口時間を実験的に求めた例 (Simpson et al., 1967)があり，隔膜の開口時間が開口面積と管断面積によって定式化されている(Drewry and Walenta, 1965). また, 隔膜を挟んだ管両端に光源および光電子増倍管等の受光装置を設置して, 隔膜開口の様子の時間変 化が調べられており(Golovastov and Bocharnikov, 2012)(Rothkopf and Low, 1974)(Simpson et al., 1967)，これらの結果 をもとに隔膜開口面積の時間変化が求められている(大田他, 1975). さらに隔膜開口時間を考慮した衝撃波形成 モデルも提案されており(生井, 松尾，1968a)(生井，松尾，1968b)(White, 1958), 開口時間が衝撃波形成に及ぼす 影響(生井他, 1978)や，隔膜の開口面積および開口形状が衝撃波形成に与える影響(Houas et al., 2012)について報告 されている.

しかしながら，これまでに実験的に調べられてきた開口度は，開口途中の隔膜を通過する光の強度計測に基づ くものが多い(Golovastov and Bocharnikov, 2012)(Rothkopf and Low, 1974)(Simpson et al., 1967). 隔膜開口形状につい ても主として破断終了後の形状に力点を置いて調べられており( Drewry and Walenta, 1965), 開口途中の開口形状 に関する研究例はほとんど無い。さらに開口時間が衝撃波形成に与える影響に関して, 実験的研究では急速開口 弁を用いて開口時間を変化させており(生井他，1978), 実際の隔膜を用いて開口時間と衝撃波形成について調べ た例は見あたらない．また，これまでの実験では比較的寸法の大きな矩形管が用いられており，水素配管のよう な内径の小さい円管での研究例は少ない.

本研究では, 隔膜開口過程の再現性を高めることで隔膜ごとの衝撃波形成のばらつきを減らすとともに，隔膜 の開口状態が衝撃波形成に及ぼす影響を実験的に調べることを目的とした. 使用する試験部は内径 $10 \mathrm{~mm}$ の管 とし，隔膜開口度の時間変化を高速度カメラを利用して求め，衝撃波形成との関係を調べた.

\section{2. 実験装置および方法}

\section{$2 \cdot 1$ 実験装置}

図 1 に本研究で用いた実験装置の概略図を示寸，実験装置は高圧水素貯蔵部，試験部，減衰部の 3 つの部分か ら構成されている.高圧水素貯蔵部と試験部は隔膜で仕切られており, 試験部および減衰部に大気圧の乾燥空気, 高圧水素貯蔵部に高圧水素を充填して隔膜を破断させ, 水素の漏洩状態を再現する. 水素は最大 $15.0 \mathrm{MPa} の$ 充填 圧力で高圧水素貯蔵部に充填した. 高圧水素貯蔵部の内径は $20 \mathrm{~mm}$, 試験部の内径は $10 \mathrm{~mm}$ であり, 隔膜を挟ん で流路断面積は流れ方向で減少する構造となっている. また高圧水素貯蔵部には汎用圧力計が取り付けられてお り，水素の充填圧力および隔膜破時の圧力を記録することができる. 高圧水素貯蔵部への水素配管にはニードル バルブが設置されており, 高圧水素貯蔵部の圧力を確認しながら充填速度を調節することで, 急激な圧力上昇に 伴う不用意な隔膜破断を防いだ. 試験部には 4 つの汎用圧力変換器(PCB 113A24)が取り付けられており, その受 圧部直径が $5.6 \mathrm{~mm}$ と試験部内径と同程度であるため, 試験部内の流れを乱さないように内径 $1 \mathrm{~mm}$, 長さ $2 \mathrm{~mm}$ の圧力導入孔を介して圧力を計測した．このように圧力変換器の受圧面が流路に直接接していないため, 衝撃波 到達時に計測される圧力の立ち上がりは比較的緩やかなものになるが，比較のために行った受圧面が直接流路に 接している場合の結果に対して，圧力立ち上がりの時刻に大きな差は見られず，その圧力の立ち上がり方も衝撃 
波による急峻なものであった，減衰部の内径は $100 \mathrm{~mm}$ ，長さは $1000 \mathrm{~mm}$ であり，その容積は試験部に比べて十 分大きいため，減衰部に到達した衝撃波や水素噴流が試験時間内に試験部に影響を及ぼすことはない.
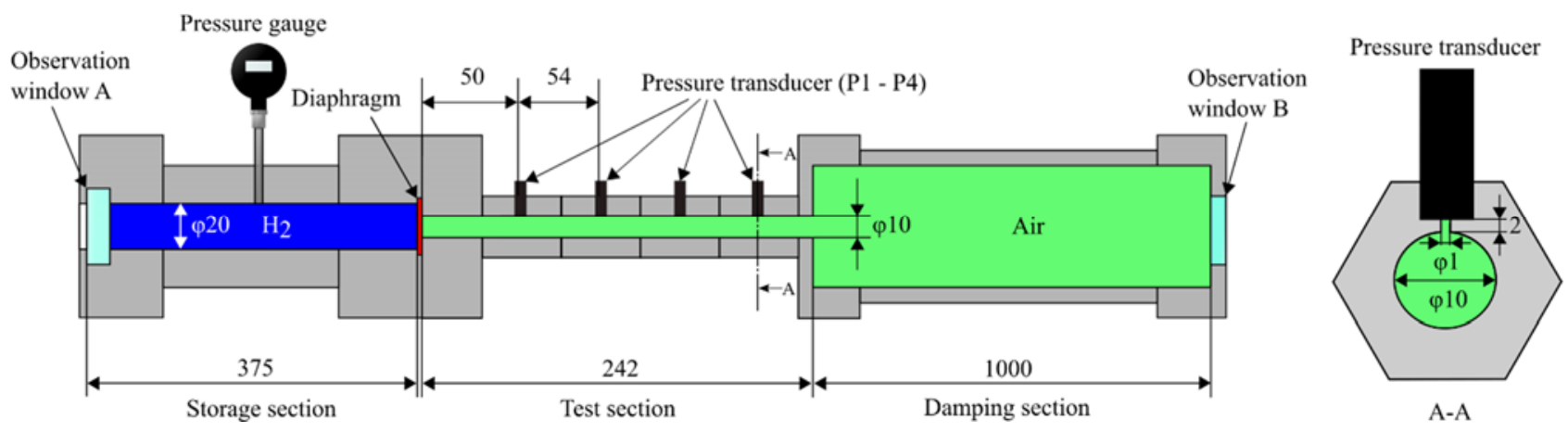

Fig. 1 Schematic of experimental apparatus.

本実験で用いた隔膜は金属板を機械加工して作成したもので，材質および厚さの組み合わせとして，アルミニ ウムは $400 \mu \mathrm{m}$ と $500 \mu \mathrm{m}$ ，銅および真鍮は $200 \mu \mathrm{m}$ である．各隔膜は破断の再現性を高めて花弁状に開口させる ために, 表面に幅約 $1 \mathrm{~mm}$, 長さ $11 \mathrm{~mm}$ の十字の溝(Score)が切られており, この溝の深さを変えることで破断圧 力(Rupture pressure)を変化させた. この際, 溝が切ってある面を試験部側に向けて隔膜を挿入することで隔膜は溝 に沿って開口する. 溝は R0.5 のボールエンドミルを用いることで形状が半円となり，すべての隔膜の溝の深さを 予め表面粗さ測定器 (Mitutoyo SJ-201) で計測する. 十字の溝の 4 箇所に対して, 溝線に直行するように十点平均 粗さを複数回計測し, 得られた溝深さのばらつきが $\pm 5 \mu \mathrm{m}$ 以内に収まる隔膜のみを使用した. このように隔膜の 溝深さから隔膜を区分し, 所望する破断条件に応じて隔膜を選定することで, 隔膜破断の再現性向上を図った. 比較のため, 溝を切っていない隔膜についても破断試験を行った.

\section{$2 \cdot 2$ 隔膜開口度}

本研究では, 隔膜開口面積の試験部断面積に対する割合を開口度と定義し, 開口度計測には, 光強度測定およ び高速度カメラによる隔膜開口画像計測の二種類の方法を試みた. 前者については, 図 1 において観測空 A から キセノンランプの白色光を入射させ，観測空 B を通した透過光強度の時間変化をフォトダイオードにより計測す る. 試験後, 破断した隔膜が挿入されたままの状態で光強度を再度計測し，このとき得られた值を開口終了状態 の光強度とした. 次に後者の計測法については, 観測空 A から入射するキセノンランプの白色光を背景光とし, 高速度カメラ(nac MEMRECAMfx K4)を用いて観測空 B 越しに隔膜を撮影する. 得られた画像を二值化して開口 部分と未開口部分とに分け，開口部分の面積を画像上で求めることで開口度を計測する．この場合も試験後に破 断した隔膜を挿入したままで撮影を行い，得られた面積を開口終了状態の面積とする。これらの開口度計測にお いて, 高圧水素の自発点火現象が開口度計測時間内で発生しない条件で実験は行われた。 なお，衝撃波速度およ び圧力の時間履歴からも隔膜開口過程の再現性確認を行った。

本研究では試験部内径が $10 \mathrm{~mm}$ であるため隔膜開口部の径は $10 \mathrm{~mm}$ 以下としかならない. 隔膜開口面積の衝

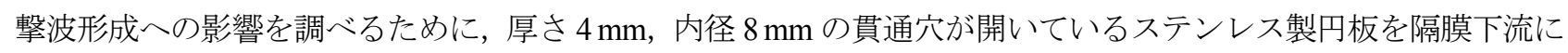
隣接するよう挿入することで，隔膜開口部の径を $8 \mathrm{~mm}$ 以下に制限することができる．このようにして隔膜開口 面積が衝撃波形成に及ぼす影響についても調べた。

\section{3. 実験結果および考察}

\section{$3 \cdot 1$ 溝なし隔膜}

表 1 に溝を切っていないアルミニウム製隔膜を破断させた場合の実験条件および結果を示す．厚さ $400 \mu \mathrm{m} の$ アルミニウム隔膜 4 枚を破断させた結果, 隔膜は圧力 $10.1 \mathrm{MPa}$ から $10.6 \mathrm{MPa}$ の範囲で破断した. 本研究で使用 する隔膜は金属板を用いて製作しており，作成過程における隔膜の歪みや，金属板の圧延方向の違いなど破断圧 
力をばらつかせる要因は複数考えられる．また同じ材質・厚さの隔膜が破断するとき，破断圧力が高いほど形成 される衝撃波は強くなると考えられるが, 表 1 の Case 1 と Case 2 を比較すると, 破断圧力と衝撃波速度の関係が 逆転していることがわかる。この原因として，隔膜の開口過程が異なっていたことが考えられる．隔膜は瞬間的 に破断したとしても，隔膜開口には少なくとも数十〜数百マイクロ秒の時間が必要となる. 図 2 は溝を切ってい ない隔膜破断時の開口過程を高速度カメラで撮影したときの画像である。この場合，隔膜は端から徐々にまくれ ながら開口し，隔膜のまくれた部分は隔膜本体からちぎれて下流方向に吹き飛ばされている．したがって最終的 な隔膜の開口面積は, 内径 $10 \mathrm{~mm}$ の管内断面積とほぼ等しくなる. 急速開口弁を用いた衝撃波管の研究(生井他, 1978)において，同じ破断圧力で実験を行う場合，開口速度が速いほど衝撃波が強まることがわかっている．した がって表 1 の Case 1 と Case 2 における破断圧力と衝撃波速度の関係逆転は, 隔膜開口速度の違いによるものと考 えられる.ところで, 溝を切っていない隔膜は毎回同じ箇所から開口を開始するわけではなく, 隔膜開口過程に おける管内の流れは管軸を中心とした軸対称となるとは限らない．そのため破断圧力を一定にしても開口状態が 一様とはならず，再現性良く衝撃波を形成することが困難となる.

Table 1 Rupture conditions for non-scored diaphragms.

\begin{tabular}{|c|c|c|c|c|c|}
\hline Case & Material & $\begin{array}{c}\text { Thickness } \\
(\mu \mathrm{m})\end{array}$ & $\begin{array}{c}\text { Rupture pressure } \\
(\mathrm{MPa})\end{array}$ & $\begin{array}{c}\text { Shock speed } \\
(\mathrm{m} / \mathrm{s})\end{array}$ & Opening ratio \\
\hline 1 & Aluminum & 400 & 10.1 & 1650 & 1.0 \\
\hline 2 & Aluminum & 400 & 10.4 & 1600 & 1.0 \\
\hline 3 & Aluminum & 400 & 10.5 & 1630 & 1.0 \\
\hline 4 & Aluminum & 400 & 10.6 & 1710 & 1.0 \\
\hline
\end{tabular}

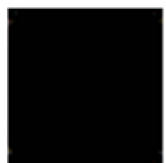

$0 \mu \mathrm{s}$

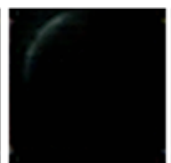

$9.5 \mu \mathrm{s}$

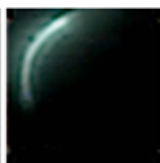

$19.0 \mu \mathrm{s}$

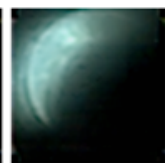

$28.5 \mu \mathrm{s}$

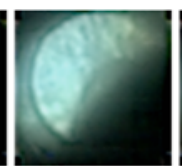

$38.0 \mu \mathrm{s}$

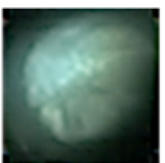

$47.5 \mu \mathrm{s}$

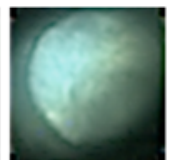

$57.0 \mu \mathrm{s}$

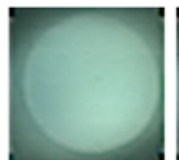

$66.5 \mu \mathrm{s}$

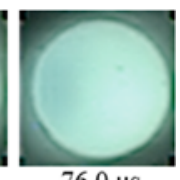

$76.0 \mu \mathrm{s}$

Fig. 2 Opening images of a non-scored diaphragm.

\section{$3 \cdot 2$ 隔膜の溝深さと破断圧力の関係}

図 3 に隔膜の厚さまたは隔膜厚さから溝深さを差し引いた值(Minimum thickness of diaphragm) と破断圧力の関係 を示す. 本研究では $3.0 \mathrm{MPa}$ から $15.0 \mathrm{MPa}$ の圧力範囲で隔膜が破断するように各隔膜に溝を切った. このとき, 溝が浅すぎる場合には隔膜は十字型の花弁状には割れず，溝が深すぎる場合は表面粗さ測定器の測定範囲を超え てしまう。このようなことが生じないように，本研究では厚さ $400 \mu \mathrm{m}$ および $500 \mu \mathrm{m}$ のアルミニウム，厚さ 200 $\mu \mathrm{m}$ の真鍮および銅の隔膜を用いた. 図 3 より隔膜の種類ごとに隔膜の厚さと破断圧力に直線関係があることが わかる．ところで矩形衝撃波管に関して，同じ材質の隔膜を用いた場合の破断圧力 $P_{r}$ は， $d$ を隔膜の厚さまたは 隔膜厚さから溝深さを差し引いた值, $b$ を隔膜が矩形に破断した際の矩形部分の一辺の長さとして

$$
P_{r} \propto d / b
$$

の関係があることが報告されており(Drewry and Walenta, 1965), 円管においても式(1)は図 3 の傾向と概ね一致し

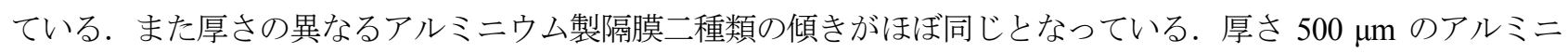
ウム製隔膜を厚さが約 $350 \mu \mathrm{m}$ になるように溝を切った場合の破断圧力は $8.5 \mathrm{MPa}$ であり, 厚さ $400 \mu \mathrm{m}$ のアルミ ニウム製隔膜も同様に厚さが約 $350 \mu \mathrm{m}$ になるよう溝を切った場合の破断圧力は $8.7 \mathrm{MPa}$ と值が近い. 溝を切っ 
ていない部分の隔膜の厚さが $100 \mu \mathrm{m}$ 異なっていても隔膜から溝深さを差し引いた值が同じであれば，破断圧力 はほぼ同じ值を示すこととなり, 式(1)と一致している. なお図 3 の傾きは真鍮, 銅, アルミニウムの順に大きく, 隔膜の厚さではなく材質の機械的強度が傾きを決定している.

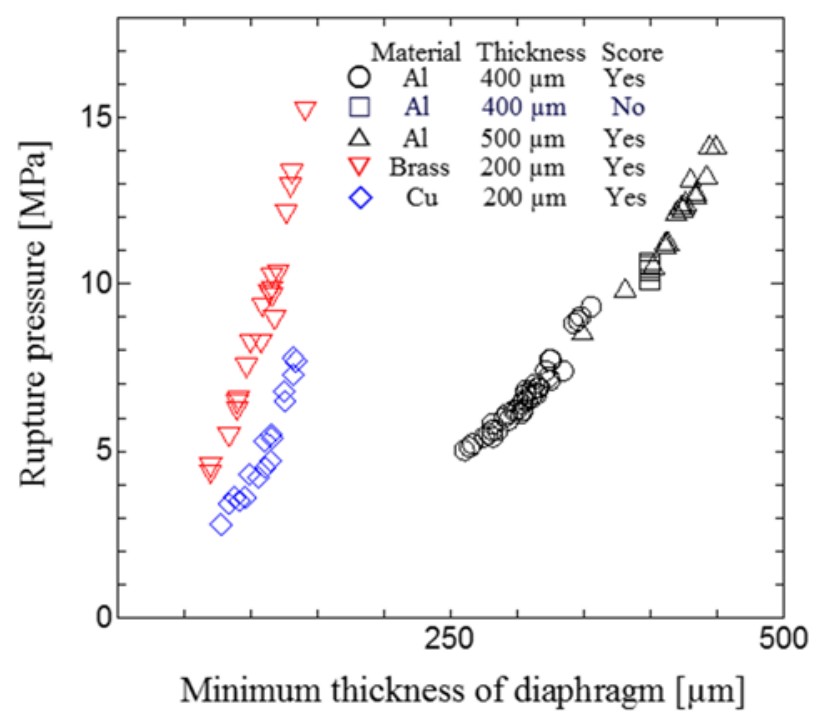

Fig. 3 Relation between minimum thickness of diaphragm and rupture pressure.

\section{$3 \cdot 3$ 隔膜開口度の計測方法}

図 4 に厚さ $400 \mu \mathrm{m}$ のアルミニウム隔膜が圧力 $8.2 \mathrm{MPa}$ で破断した際の, 光強度および高速度カメラ撮影画像 から求めた開口度の時間変化を示す. 前者から得られる開口度は最終的に 1 まで到達しているのに対して, 後者 では 0.9 未満である. 光強度による開口度測定では, まず隔膜のない状態での光強度を計測し, 次に隔膜破断時 の光強度を計測することで管断面積を 1 としたときの開口度を求めている．しかしながら開口とともに得られる 開口度は 1 を越えて上昇する結果となった。一方で高速度カメラ画像を用いる方法では，管断面積を 1 とするた めに原理的に開口度が 1 を超えることはない. 高速度カメラによる代表的な隔膜開口過程は図 5(a)に示寸. 図 5(b) は隔膜がすべて開いた時の画像であり, 図 5(c)は隔膜がないときの画像である.

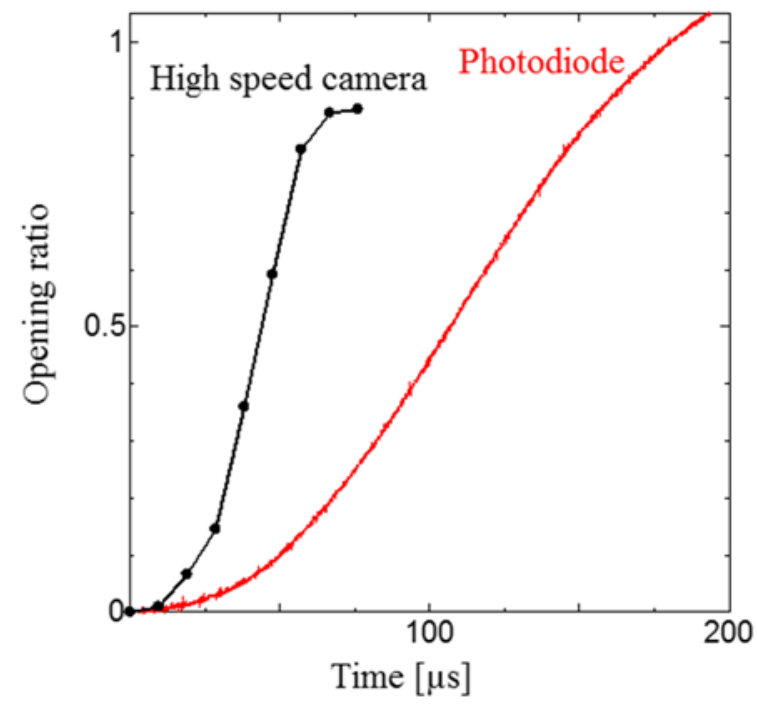

Fig. 4 Opening ratio of a scored diaphragm measured with high-speed camera and photodiode (aluminum diaphragm: $400 \mu \mathrm{m}$ in thickness, rupture pressure: 8.2 $\mathrm{MPa})$.

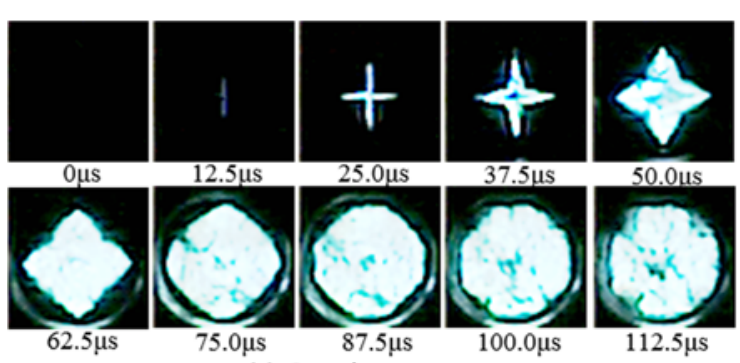

(a) Opening process

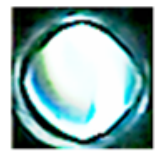

(b) Final opened area

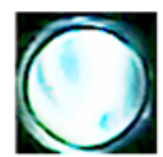

(c) Tube cross section
Fig. 5 Opening images of a scored-diaphragm. 
図 4 において，光強度による方法は高速度カメラ画像による方法よりも，開口時間が明らかに長い. 図 5(a) と 図 5(b)との比較から， $t=75.0 \mu \mathrm{s}$ でほぼ開口終了となることがわかるが， $t=87.5 \mu \mathrm{s}$ 以降でも開口部外側における 輝度が高くなっていき, $t=112.5 \mu \mathrm{s}$ では管断面の大部分が明るくなっている. これは隔膜の開口後に噴出してく る高圧水素がキセノン光を屈折させるためと考えられる，そのため，光強度を用いた開口度測定では実際とは異 なる開口時間をもたらすことになる，また本実験では，隔膜を通過するキセノン光を試験部および減衰部を通過 させて，観測空 B 側に設置されたフォトダイオードで検出しているが，キセノン光を完全に平行光とすることは 困難であった。 したがって, キセノン光が高圧水素噴流によって屈折したときに最大光強度になる結果, 開口度 が 1 を超過すると考えられ，光強度による開口度測定では，本研究では開口時間および開口度ともに実際とは異 なる結果が得られることになる，以上から，本節以降の開口度測定は高速度カメラ画像に基づくものとする.

\section{$3 \cdot 4$ 開口過程の再現性}

表 2 に厚さ $400 \mu \mathrm{m}$ のアルミニウム製隔膜に同じ溝を切り破断させた二つの場合の実験条件と結果を示す。こ のときの圧力変換器 P1 によって得られた圧力の時間履歴を図 6 に, 開口度の時間変化を図 7 にそれぞれ示寸. 表 2, 図 6, 図 7 より, 二つの隔膜開口過程と圧の時間変化がほぼ同じであることから, 隔膜に精度よく溝を切 ることで高い実験の再現性が得られることが確認できる.

Table 2 Rupture conditions for scored diaphragms made of aluminum.

\begin{tabular}{|c|c|c|c|c|c|c|}
\hline Case & Material & $\begin{array}{c}\text { Thickness } \\
(\mu \mathrm{m})\end{array}$ & $\begin{array}{c}\text { Rupture pressure } \\
(\mathrm{MPa})\end{array}$ & $\begin{array}{c}\text { Shock speed } \\
(\mathrm{m} / \mathrm{s})\end{array}$ & $\begin{array}{c}\text { Opening time } \\
(\mu \mathrm{s})\end{array}$ & Opening ratio \\
\hline 5 & Aluminum & 400 & 7.2 & 1430 & 104.8 & 0.86 \\
\hline 6 & Aluminum & 400 & 7.1 & 1420 & 104.8 & 0.85 \\
\hline
\end{tabular}

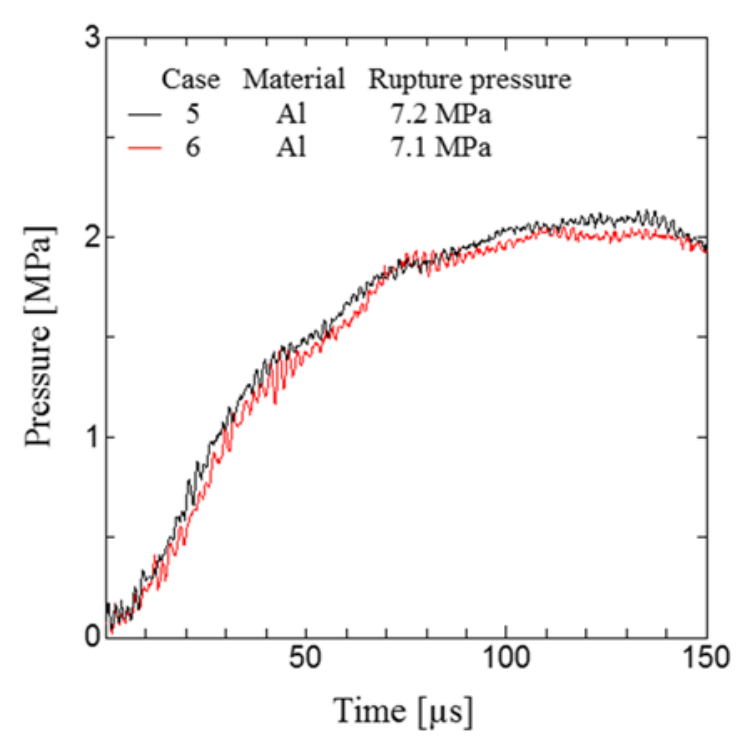

Fig. 6 Time history of measured pressure at P1.

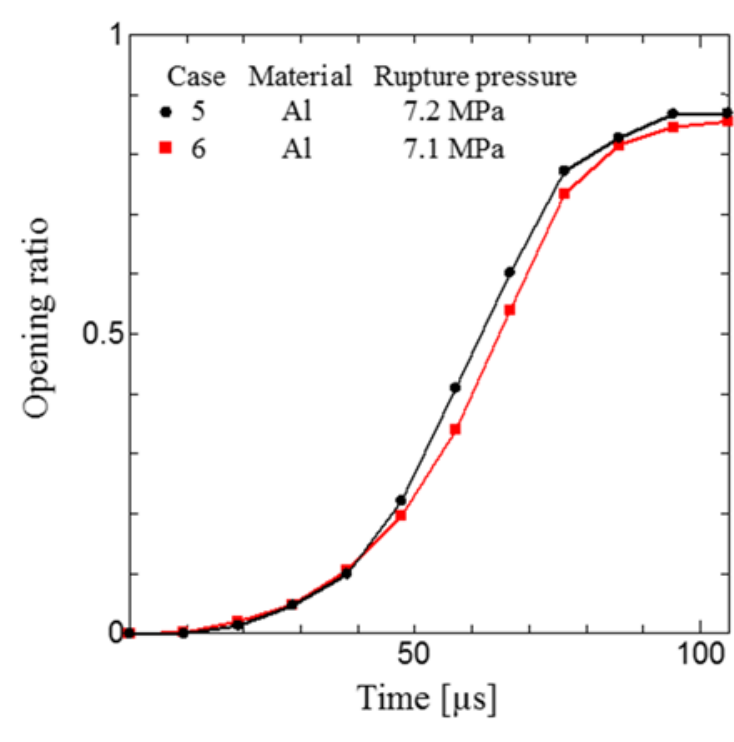

Fig. 7 Opening ratio of scored diaphragms with almost the same rupture pressure.

\section{$3 \cdot 5$ 破断圧力の影響}

表 3 に厚さ $200 \mu \mathrm{m}$ の真鍮製隔膜を $6.6 \mathrm{MPa}, 8.0 \mathrm{MPa}, 12.5 \mathrm{MPa}$ で破断させた際の結果を，図 8 にその際の隔 膜開口度の時間変化を示寸。これらの結果より，同じ材質・厚さの隔膜破断では，破断圧力が高いほど形成され る衝撃波が強くなり，開口時間が短くなることがわかる．これは水素の充填圧力が高いほど破断時に隔膜を強く 押し広げるためと理解できる. また充填圧力が高いと破断後に噴出する高圧水素によって生ずる圧縮波群は強く, 
形成される衝撃波も強くなる.このことは図 7 の Case 5, Case 6 と図 8 の Case 9 では開口時間はほぼ同じである ものの, 破断圧力が低い Case 9 は Case 5, Case 6 よりも衝撃波の強度が弱くなっていることからも確認できる.

表 3 において，Case 7 と Case 8 の開口面積はほぼ同じであるが，Case 9 はわずかに小さい. 金属製隔膜におい て破断圧力が高いほど開口時間が短くなることが知られている(大田他，1975)が，本実験条件のように円管の場 合では，破断圧力は最終的な開口面積にも影響を与えている．円管において十字の溝を切った隔膜を破断させる と，図 5 の開口画像のように溝を切った金属製隔膜は圧力とともに開口面積を増大させ，最終的には矩形から円 形へと開口形状を変えてゆく．さらに溝を浅くして破断圧力を高めた場合は，溝に沿って開口寸ることなく図 2 のように隔膜はちぎれて分裂し, 開口面積は管断面積と等しくなる.したがって Case 8 と Case 9 の間に開口度が 0.92 となる破断圧力が存在し, それを超えても隔膜が分裂しない限り開口度は 0.92 より大きくならないと思われ る. さらに表 2 の Case 5, Case 6 と比較すると, 破断圧力が低い場合でも真鍮製隔膜の開口面積の方が大きいこ とがわかる．これは本研究において使用される真鍮製隔膜はアルミニウム製隔膜より薄いため，低い破断圧力で も一度隔膜が破断してしまえば真鍮製隔膜の方が容易に開口面積が広がってしまうためである.

Table 3 Effects of rupture pressure on opening conditions of diaphragms made of brass.

\begin{tabular}{|c|c|c|c|c|c|c|}
\hline Case & Material & $\begin{array}{c}\text { Thickness } \\
(\mu \mathrm{m})\end{array}$ & $\begin{array}{c}\text { Rupture pressure } \\
(\mathrm{MPa})\end{array}$ & $\begin{array}{c}\text { Shock speed } \\
(\mathrm{m} / \mathrm{s})\end{array}$ & $\begin{array}{c}\text { Opening time } \\
(\mu \mathrm{s})\end{array}$ & Opening ratio \\
\hline 7 & Brass & 200 & 12.5 & 1750 & 57.1 & 0.92 \\
\hline 8 & Brass & 200 & 8.0 & 1520 & 76.2 & 0.92 \\
\hline 9 & Brass & 200 & 6.6 & 1380 & 104.8 & 0.89 \\
\hline
\end{tabular}

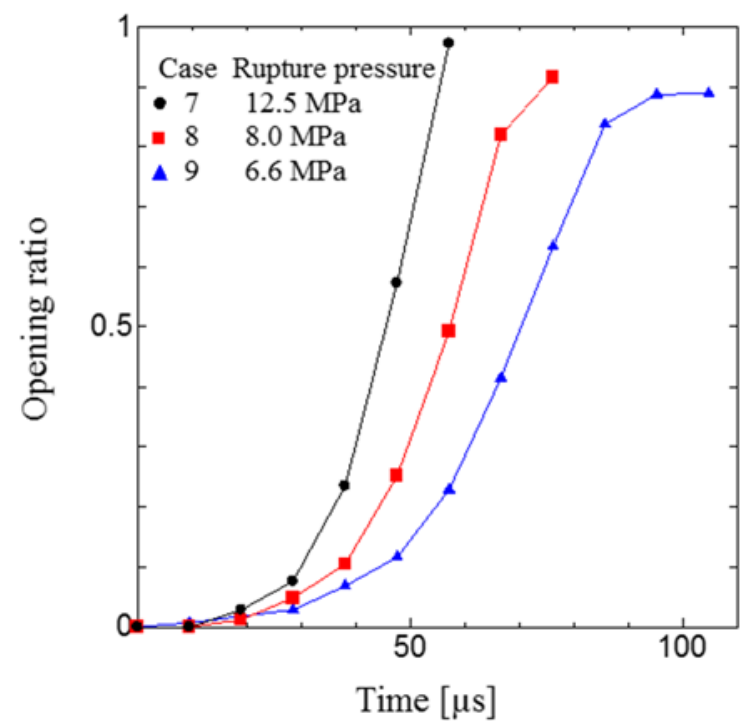

Fig. 8 Opening ratio of scored diaphragms for various rupture pressures.

矩形管において十字の溝を切った隔膜の場合, 理想的な開口過程では十字形が均等にその線幅を増やしながら 開口し，やがてその十字を対角線とする矩形形状になる(Rothkopf and Low, 1974). このとき, 時刻 $t$ での開口度 $R(t)$ は，衝撃波管の通路幅を $D$, 隔膜の開口時間を $t_{o p}$, 時間を $t_{o p}$ で除した無次元時間を $\tau$ とすると,

$$
R(t)=1-\cos \left(\frac{\pi}{2} \tau^{2}\right), \quad \tau \equiv t / t_{o p} \leq 1
$$

で与えられる(大田他，1975). しかしながら式(2)では, 開口度 $20 \%$ に到達するのに開口時間の約 65\%を要し，こ れは開口度の時間変化を求めた実験結果(Golovastov and Bocharnikov, 2012)(Rothkopf and Low, 1974)(Simpson et al., 1967)よりも長い. 図 7, 図 8 からわかるように, 開口度は最初緩やかに上昇した後にある時刻から急峻に上昇し, 
開口終期では再び緩やかな上昇となっている，本研究では，式(2)を開口度の実駼結果に適合するように以下のよ うに修正を行った。

$$
R(t)=R_{f} \cos \left(\frac{\pi}{2} 0.4^{2}\right)-\cos \left\{\frac{\pi}{2}(\tau+0.4)^{2}\right\} /\left\{\cos \left(\frac{\pi}{2} 0.4^{2}\right)-\cos \left(\frac{\pi}{2} 1.4^{2}\right)\right\}, \quad \tau \equiv t / t_{o p} \leq 1
$$

ここで， $R_{f}$ は $t=t_{o p}$ で得られる最終的な開口度である. 表 2 の Case 5 および表 3 の Case 9 の実験結果に対して式 (2)および式(3)を適用した結果を図 9 に示寸. 式(2)は初期の開口度を過小評価しているが，式(3)は開口時間全域 にわたり実験結果と一致している．特にアルミニウム隔膜の破断の方が真鍮破断よりも式に良く一致しており， 本実験において隔膜厚さにかかわらず全てのアルミニウム隔膜で良く一致することが確認された．矩形管におい て十字の溝を切った隔膜の場合，アルミニウム製隔膜は理想的な開口過程になる一方で，真鍮製隔膜は十字形が 均等に開口せず開口形状もきれいな矩形にならないことが知られている(Rothkopf and Low, 1974). したがって本 研究においても，アルミニウム製隔膜は理想的に開口し真鍮製隔膜の開口はばらつくためアルミニウム製隔膜の 方が式(3)に良く一致したと考えられる.

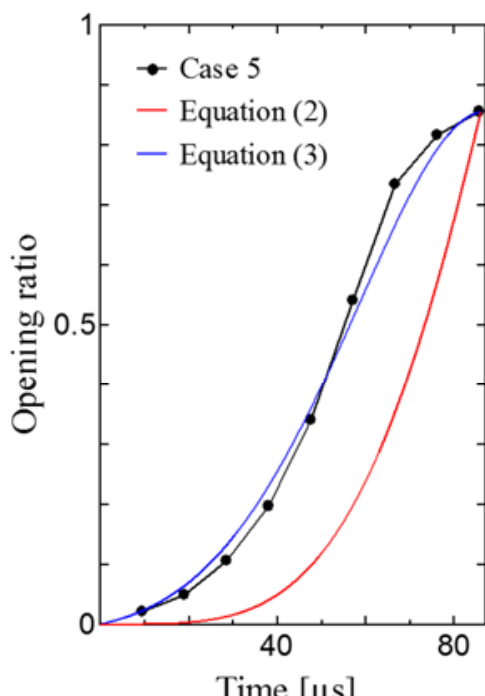

(a) Aluminum diaphragm

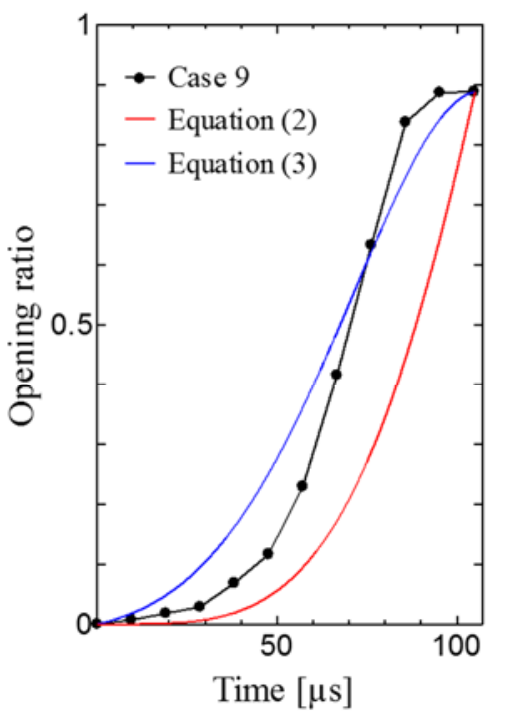

(b) Brass diaphragm

Fig. 9 Comparison of opening ratio between experimental and calculated results.

\section{$3 \cdot 6$ 隔膜材質および厚さの影響}

表 4 に厚さ $200 \mu \mathrm{m}$ の真鍮製隔膜と，厚さ $400 \mu \mathrm{m}, 500 \mu \mathrm{m}$ のアルミニウム製隔膜を破断させたときの結果を， またそのときの開口度の時間変化を図 10 に示寸. 破断圧力が $8.0 \mathrm{MPa}$ と一定であっても, 隔膜の材質もしくは厚 さが異なる場合には開口時間に差が生じており，開口時間が短いほじ衝撃波が強い結果となっている．また図 10 より，最終的な開口面積は開口時間が短いほど大きくなっており，各種隔膜を同一圧力で破断させた場合には， 図 10 から分かるよう開口速度が大きいほど強い衝撃波が形成されると考えられる.

矩形管において十字の溝を切った隔膜を破断させたときの開口時間 $t_{o p}$ は, 実験条件に依存する定数を $K$, 隔膜 の密度を $\rho$ とすると

$$
t_{o p}=K \sqrt{\rho b d / P_{r}}
$$

と見積もられる(Rothkopf and Low, 1974). Case 10 から Case 12 において, 破断圧力が同じであり, 隔膜が試験部 内径に沿って開口したとすれば，開口時間は隔膜材質の密度および隔膜厚さから溝深さを差し引いた值の平方根 に比例する．隔膜厚さから溝深さを差し引いた值は, Case 10 では約 $100 \mu \mathrm{m}$, Case 11 では約 $350 \mu \mathrm{m}$, Case 12 で 
は約 $400 \mu \mathrm{m}$ であり，この条件のもとで式(4)から開口時間を計算すると Case 10，Case 11，Case 12 の順に短くな り，実験結果と一致する. また過去の研究(Simpson et al., 1967)(Drewry and Walenta, 1965)において定数 $K$ は 0.91 から 0.95 の範囲をとるが, Case 11 の場合 $K=0.93$ となり実験結果と過去の研究結果は一致する. しかしながら, Case 10 では $K=0.90$ となりわずかに一致せず，Case 12 では $K=1.06$ となりそのずれは比較的大きい. Case 10 が 一致しない理由として，真鍮製隔膜の開口面積が円管断面積に近づいたためと考えられる．矩形管における十字 の溝を切った隔膜の破断の場合，本研究における真鍮製隔膜は薄いため，矩形状よりも広く開口し実際の開口時 間は計算値よりも長くなる．その結果，定数 $K$ の值は低くなると考えられる．また Case 12 では，隔膜が厚いた めに開口過程が十分に進行しないためと思われる. Case 12 の結果からわかるように, 本実験条件では厚さ $500 \mu \mathrm{m}$ のアルミニウム製隔膜の開口面積は管断面積より明らかに小さく，矩形状に開口するよりも早期に開口過程を終 了してしまう。 そのため実際の開口時間は計算值よりも短くなり, 定数 $K$ の值は大きくなると考えられる. した がって，円管における真鍮製隔膜や比較的厚めの隔膜の破断では，開口時間は矩形管での実験結果と異なるもの となり，形成される衝撃波に差異が生ずることが予想される.

Table 4 Effects of material and thickness on shock formation and opening process.

\begin{tabular}{|c|c|c|c|c|c|c|c|c|}
\hline Case & Material & $\begin{array}{c}\text { Thickness } \\
(\mu \mathrm{m})\end{array}$ & $\begin{array}{l}\text { Rupture pressure } \\
(\mathrm{MPa})\end{array}$ & $\begin{array}{c}\text { Shock speed } \\
(\mathrm{m} / \mathrm{s})\end{array}$ & $\begin{array}{l}\text { Opening time } \\
(\mu \mathrm{s})\end{array}$ & $\begin{array}{l}\text { Calculated opening time } \\
(\mu \mathrm{s})\end{array}$ & Opening ratio & $\begin{array}{l}\text { Density } \\
\left(\mathrm{g} / \mathrm{cm}^{3}\right)\end{array}$ \\
\hline 10 & Brass & 200 & 8.0 & 1520 & 76.2 & 85 & 0.91 & 8.5 \\
\hline 11 & Aluminum & 400 & 8.0 & 1460 & 85.7 & 91 & 0.85 & 2.7 \\
\hline 12 & Aluminum & 500 & 8.0 & 1340 & 114.3 & 108 & 0.63 & 2.7 \\
\hline
\end{tabular}

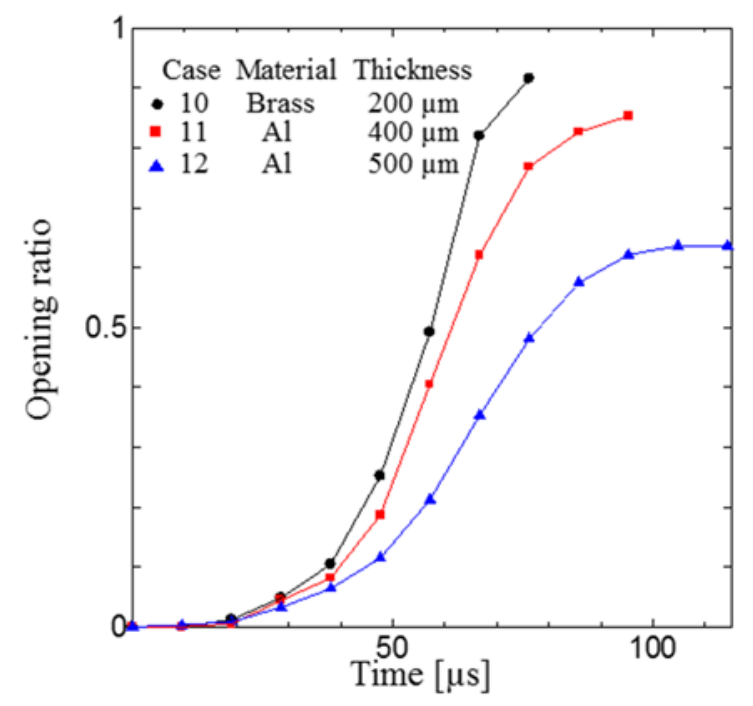

Fig. 10 Opening ratio of different diaphragms with the same rupture pressure.

\section{$3 \cdot 7$ 開口面積の衝撃波形成への影響}

本研究では破断の再現性を高めるために隔膜に十字の溝を切っているが，ごくまれに図 11 に示すように花弁 状に割れないことがあった。このとき, 図 3 に示される溝深さから決まる破断圧力よりも低い圧力で隔膜は破断 した.このような割れ方をする原因として, 溝を機械加工する際に十字の縦と横で溝深さに差が生じたためと考 えられる. 開口面積が極端に小さくなるような隔膜破断では, 同じ隔膜・破断圧力と比較して, 衝撃波の強さが 著しく低下した。

隔膜開口面積が衝撃波形成に及ぼす影響を調べるために，直径 $8 \mathrm{~mm}$ の孔の開いたステンレス製円板を隔膜に 密着させて挿入し, 開口部が $8 \mathrm{~mm}$ 超えないよう意図的に開口面積を制限した実験を行った。このようにして 厚さ $400 \mu \mathrm{m}$ のアルミニウム製隔膜を破断させた結果を表 5 に，その際の開口度の時間変化を図 12 に示寸．表 5 
には比較のため開口面積を制限しない場合の結果を Case 16 として示してある. Case 13，Case 14，Case15 を比較 すると, 隔膜の開口面積を制限した場合でも破断圧力が大きくなると衝撃波の強さおよび開口面積が大きくなり， 開口時間が短くなることがわかる. 開口速度の大きい順に衝撃波の強度が決定されているのは図 12 から明らか である. 次に Case 13 と Case 16 を比較すると, Case 13 は破断圧力が $1.0 \mathrm{MPa}$ 程高いものの衝撃波速度は Case 16 とほぼ同じ值であり，開口面積を制限した場合には同じ強さの衝撃波形成にはより高い破断圧力が必要であるこ とがわかる. また図 12 において Case 13 と Case 16 は大きく異なる開口度の時間変化を示しながら, 同じ強さの 衝撃波を形成することから，開口時間と開口面積はそれぞれが衝撃波の強さに影響を与えていることがわかる.

上述したように，なかでも開口速度が衝撃波の強さに大きく影響を及ぼすので，開口時間が短い方がより強い 衝撃波を生成する. Case 13, Case 14, Case 15 では，流路直径 $10 \mathrm{~mm}$ に対して開口部は直径 $8 \mathrm{~mm}$ 以下に制限さ れるので, 開口部から噴出する水素の体積流量は少なく, 衝撃波も弱くなる.

Table 5 Effects of opened area on shock formation and opening conditions for diaphragms made of aluminum.

\begin{tabular}{|c|c|c|c|c|c|c|c|}
\hline Case & Material & $\begin{array}{c}\text { Thickness } \\
(\mu \mathrm{m})\end{array}$ & $\begin{array}{c}\text { Rupture pressure } \\
(\mathrm{MPa})\end{array}$ & $\begin{array}{c}\text { Shock speed } \\
(\mathrm{m} / \mathrm{s})\end{array}$ & $\begin{array}{c}\text { Opening time } \\
(\mu \mathrm{s})\end{array}$ & Opened ratio & Area Restriction \\
\hline 13 & Aluminum & 400 & 8.5 & 1440 & 66.7 & 0.56 & Yes \\
\hline 14 & Aluminum & 400 & 7.8 & 1380 & 76.2 & 0.55 & Yes \\
\hline 15 & Aluminum & 400 & 6.4 & 1240 & 87.5 & 0.44 & Yes \\
\hline 16 & Aluminum & 400 & 7.5 & 1440 & 85.7 & 0.85 & No \\
\hline
\end{tabular}
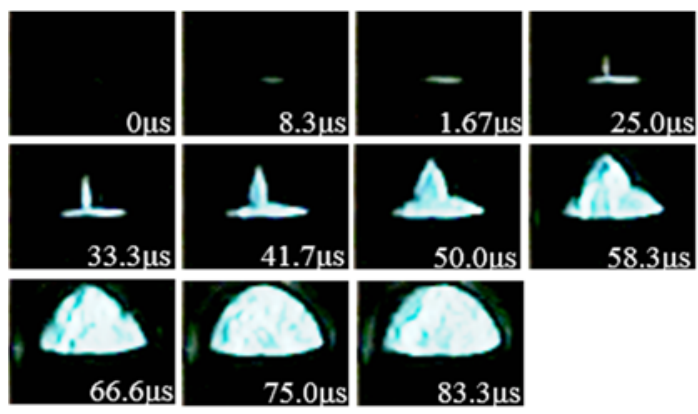

(a) Opening process

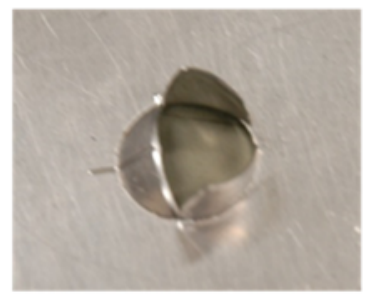

(b) Opened diaphragm

Fig. 11 Opening images of a scored diaphragm for non-

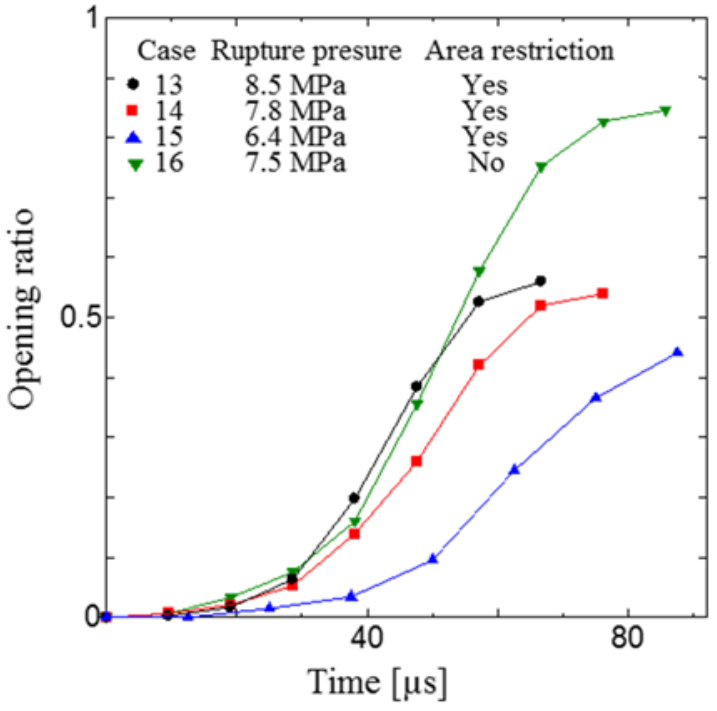

Fig. 12 Opening ratio of aluminum diaphragms for different opened area at various rupture pressure. ideal rupture.

\section{$3 \cdot 8$ 隔膜の開口と衝撃波の形成}

有限な時間での隔膜の開口が衝撃波の形成に与える影響に関して, 隔膜が完全に開いた瞬間に発生する圧縮波 が先行する衝撃波に追いついたとき, 最大強度の衝撃波が形成されると説明されている(生井他，1978). 隔膜の 開口過程初期においては球面状の弱い衝撃波が発生し，開口が進むにつれて次々に発生する圧縮波が先行する弱 い衝撃波に追いつき強める. そしてこれらの後続圧縮波による連続的な加速過程の結果, 衝撃波が形成されると ともに伝播速度は最大となる. 
図 13 に Case 6 およびCase 11 における開口度の時間変化と各時刻における先行する衝撃波の位置を示す. 4 つの圧力変換器(P1-P4)がそれぞれ圧力上昇を検知した時間を先行する衝撃波が到達した時間としており, 隔膜 挿入位置を $x=0 \mathrm{~mm}$ とした. 点線は圧力変換器 $\mathrm{P} 1$ および $\mathrm{P} 2$ で得られた先行する衝撃波の到達時間を結んだ直 線を $x=0 \mathrm{~mm}$ まで延長したものである. Case 6 と Case 11 を比較すると, 破断圧力は Case 11 が $0.9 \mathrm{MPa}$ 程度大 きいため，開口時間も短い。また衝撃波速度は Case 11 の方が Case 6 よりも $30 \mathrm{~m} / \mathrm{s}$ 程度わずかに速い. Case 11 の $x=50 \mathrm{~mm}$ への到達時間が Case 6 よりも約 $20 \mu \mathrm{s}$ 早いのは, Case 11 の開口時間が約 $19 \mu \mathrm{s}$ 短いためと考えられ る. 隔膜が開口してから先行する衝撃波が伝播する距離は隔膜の開口速度に大きく影響を受ける.

先行する衝撃波の位置を示寸実線がどちらの場合も徐々に傾きを増しているため，先行する衝撃波はわずかに 速度を増しながら伝播していることがわかるが，その変化が微小なことから $x=50 \mathrm{~mm}$ の位置で既に衝撃波は形 成されていると考えられる. また $x=50 \mathrm{~mm}$ における先行する衝撃波を形成した圧縮波が発生する時刻はそれぞ れ $t_{a}, t_{b}$ よりも前である. $t_{a}, t_{b}$ において隔膜の開口状態を考えると, Case 6 およびCase 11 ともに開口過程は完 全に終了していないがこの時刻ではどちらの場合の隔膜も最終的な開口面積の 9 割以上が開いており，その後の 開口は緩やかになる。したがって衝撃波を形成する圧縮波は，開口速度の大きな期間に発生していることがわか る.

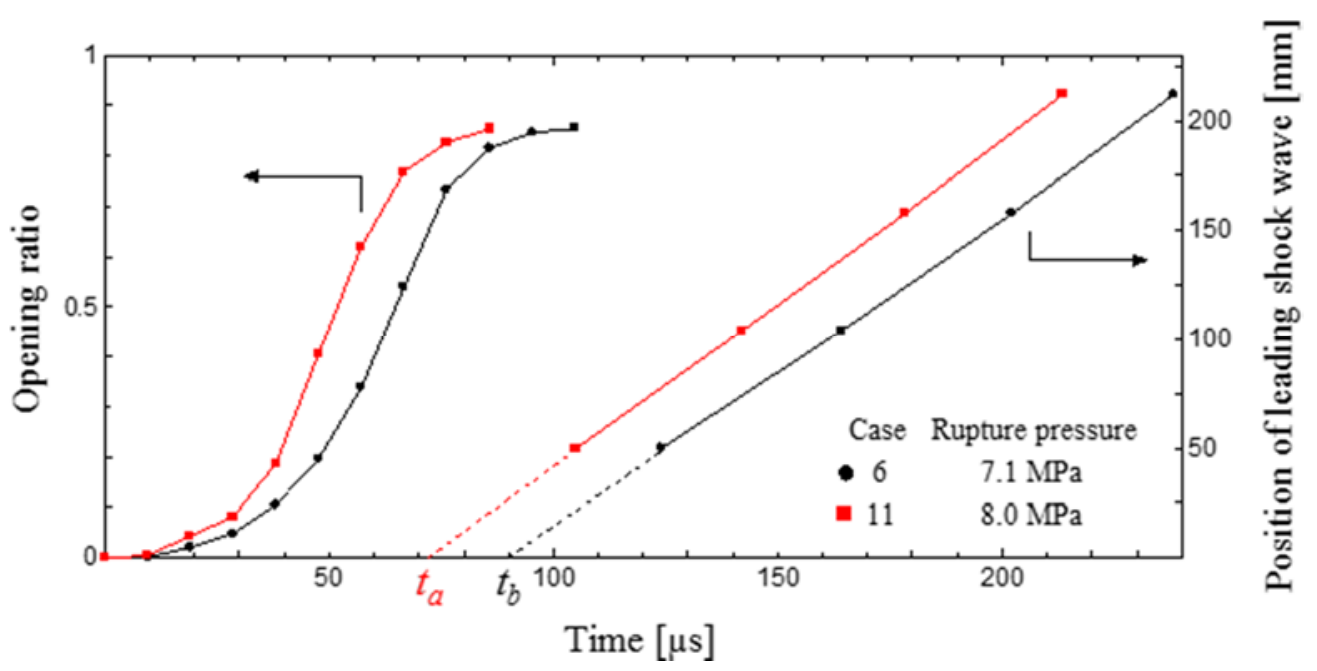

Fig. 13 Opening ratio and position of leading shock wave.

\section{4. 結 言}

破断再現性を高めるために表面に十字の溝を切った隔膜を用いて, $3.5 \mathrm{MPa}$ から $15.0 \mathrm{MPa}$ で充填された水素を 内径 $10 \mathrm{~mm}$ の管に放出することで衝撃波を形成させた. 隔膜の上流側にキセノンランプを設置し, 隔膜開口の様 子を高速度カメラで撮影することで, 開口度を計測した. このとき, 隔膜の材質, 厚さ, 溝深さ, 開口面積を変 えることで，隔膜の開口状態ならびに衝撃波形成に及ぼす影響を調べた結果，以下の知見を得た.

（1）開口度の時間変化を光強度により計測する方法では, 開口時間および開口度ともに高速度カメラ画像に基 づく方法とは異なった。

（2） 溝の深さを精度よく変化させることで, 管路内圧力の時間変化, 衝撃波伝播速度, 隔膜開口度の時間変化 の高い再現性が得られた。

（3） 円管の隔膜開口面積の時間変化を求める修正式を提案した.

（4）隔膜の材質, 厚さ, 溝深さを変化させることで, 破断圧力一定の条件で開口速度を変化させる実験を行っ た結果，開口速度が大きいほど形成される衝撃波が強くなる。

（5）隔膜破断によって形成される衝撃波の強さは，開口面積の制限または開口時間が延びることで弱くなる. 


\section{文献}

Drewry, J. E. and Walenta, Z. A., Determination of Diaphragm opening-times and use of diaphragm particle traps in a hypersonic shock tube, UTIAS Technical Note, No. 90 (1965).

Dryer, F. L., Chaos, M., Stein J. N., Alpert, J. Y. and Homer, C. J., Spontaneous ignition of pressurized releases of hydrogen and natural gas into air, Combustion Science and Technology, Vol.4, No.179 (2007), pp.663-694.

Golovastov, S. and Bocharnikov, V., The influence of diaphragm rupture rate on spontaneous self-ignition of pressurized hydrogen: Experimental investigation, International Journal of Hydrogen Energy, Vol.37 (2012), pp.10956-10962.

Golub, V. V., Baklanov, D. I., Golobastov, S. V., Ivanov, M. F., Laskin, I. N., Saveliev, A. S., Semin, N. V. and Volodin, V. V., Mechanisms of high-pressure hydrogen gas self-ignition in tubes, Journal of Loss Prevention in the process industries, Vol.21 (2008), pp.185-198.

Houas, L., Biamino, L., Mariani, C., Igra, O., Jourdan, G. and Massol, A., The effects that changes in the diaphragm aperture have on the resulting shock tube flow, Shock Waves, Vol.22 (2012), pp.287-293.

生井武文, 松尾一泰, 衝撃波管の空力特性に関する研究（第 1 報，管径が性能に及ぼす影響），日本機械学会論文 集, Vol.34, No.267 (1968a), pp. 1961-1968.

生井武文, 松尾一泰, 衝撃波管の空力特性に関寸る研究（第 2 報, 衝撃波の形成について），日本機械学会論文集， Vol.34, No.267 (1968b), pp. 1969-1976.

生井武文, 松尾一泰，山本芳久，衝撃波管用急速開口弁の研究（第 2 報，衝撃波の形成），日本機械学会論文集， Vol.44, No.385 (1978), pp. 3109-3115.

Lee, H. J., Kim, Y. R., Kim, S. H. and Jeung, I. S., A flow visualization study on self-ignition of high pressure hydrogen gas released into a tube, Proceedings of the Combustion institute, Vol.34 (2013), pp.2057-2064.

Mogi, T., Wada, Y., Ogata, Y. and Hayashi, A. K., Self-ignition and flame propagation of high-pressure hydrogen jet during sudden discharge from a pipe, International Journal of Hydrogen Energy, Vol.34, No.14 (2009), pp.5810-5816.

大田英輔, 田島清影, 斉藤正泰, 衝撃波管の隔膜の開口に伴う二次元流（第 1 報, 実験と数值解析）, 日本機械学 会論文集, Vol.41, No.353 (1975), pp.355-3525.

Rothkopf, E. M. and Low, W., Diaphragm opening process in shock tubes, The Physics of Fluids, Vol.17, No.6 (1974), pp.11691173.

Simpson, C. J. S. M., Chandler, T. R. D. and Bridgman, K. B., Effect on shock trajectory of the opening time of diaphragms in a shock tube, The Physics of Fluids, Vol.10, No.9 (1967), pp.1894-1896.

武野計二, 橋口和明，岡林一木，千歳敬子，串山益子，野口文子，高圧水素噴流への着火爆発および拡散火炎に関 する研究, 会誌『安全工学』, Vol.44, No.6 (2005), pp.398-406.

White, D. R., Influence of diaphragm opening time on shock-tube flows, Journal of Fluid Mechanics, Vol.4 (1958), pp.585599.

\section{References}

Drewry, J. E. and Walenta, Z. A., Determination of Diaphragm opening-times and use of diaphragm particle traps in a hypersonic shock tube, UTIAS Technical Note, No. 90 (1965).

Dryer, F. L., Chaos, M., Stein J. N., Alpert, J. Y. and Homer, C. J., Spontaneous ignition of pressurized releases of hydrogen and natural gas into air, Combustion Science and Technology, Vol.4, No.179 (2007), pp.663-694.

Golovastov, S. and Bocharnikov, V., The influence of diaphragm rupture rate on spontaneous self-ignition of pressurized hydrogen: Experimental investigation, International Journal of Hydrogen Energy, Vol.37 (2012), pp.10956-10962.

Golub, V. V., Baklanov, D. I., Golobastov, S. V., Ivanov, M. F., Laskin, I. N., Saveliev, A. S., Semin, N. V. and Volodin, V. V., Mechanisms of high-pressure hydrogen gas self-ignition in tubes, Journal of Loss Prevention in the process industries, Vol.21 (2008), pp.185-198.

Houas, L., Biamino, L., Mariani, C., Igra, O., Jourdan, G. and Massol, A., The effects that changes in the diaphragm aperture have on the resulting shock tube flow, Shock Waves, Vol.22 (2012), pp.287-293.

Ikui, T. and Matsuo, K., Investigation of the aerodynamic characteristics of the shock tubes: (part 1, the effects of tube diameter on the tube performance), Transactions of the Japan Society of Mechanical Engineers, Vol.34, No.267 (1968a), pp. 19611968 (in Japanese).

Ikui, T. and Matsuo, K., Investigation of the aerodynamic characteristics of the shock tubes: (part 2, on the formation of shock waves), Transactions of the Japan Society of Mechanical Engineers, Vol.34, No.267 (1968b), pp. 1969-1976 (in Japanese). 
Ikui, T., Matsuo, K. and Yamamoto, Y., Fast-acting valves for use in shock tubes: (part 2, formation of shock waves), Transactions of the Japan Society of Mechanical Engineers, Vol.44, No.385 (1978), pp. 3109-3115 (in Japanese).

Lee, H. J., Kim, Y. R., Kim, S. H. and Jeung, I. S., A flow visualization study on self-ignition of high pressure hydrogen gas released into a tube, Proceedings of the Combustion institute, Vol.34 (2013), pp.2057-2064.

Mogi, T., Wada, Y., Ogata, Y. and Hayashi, A. K., Self-ignition and flame propagation of high-pressure hydrogen jet during sudden discharge from a pipe, International Journal of Hydrogen Energy, Vol.34, No.14 (2009), pp.5810-5816.

Outa, H., Tajima, H. and Saito, M., Unsteady two-dimensional flow in a shock tube caused by diaphragm opening: (first report, experimental study and finite difference analysis), Transactions of the Japan Society of Mechanical Engineers, Vol.41, No.353 (1975), pp.355-3525 (in Japanese).

Rothkopf, E. M. and Low, W., Diaphragm opening process in shock tubes, The Physics of Fluids, Vol.17, No.6 (1974), pp.11691173.

Simpson, C. J. S. M., Chandler, T. R. D. and Bridgman, K. B., Effect on shock trajectory of the opening time of diaphragms in a shock tube, The Physics of Fluids, Vol.10, No.9 (1967), pp.1894-1896.

Takeno, K., Hashiguchi, K., Okabayashi, K., Chitose, K., Kushiyama, M. and Noguchi, F., Experimental study on open jet diffusion flame and unconfined explosion for leaked high-pressure hydrogen, Journal of Society for Safety Engineering, Vol.44, No.6 (2005), pp.398-प० (in Japanese).

White, D. R., Influence of diaphragm opening time on shock-tube flows, Journal of Fluid Mechanics, Vol.4 (1958), pp.585599. 